\title{
Effects of 8 chemical and bacterial additives on the quality of corn silage
}

\author{
O. C. M. Queiroz, ${ }^{*}$ K. G. Arriola, ${ }^{*}$ J. L. P. Daniel, $\dagger$ and A. T. Adesogan*1 \\ *Department of Animal Sciences, Institute of Food and Agricultural Sciences, University of Florida, Gainesville 32606 \\ †Department of Animal Science, University of São Paulo, Luiz de Queiroz College of Agriculture, Piracicaba, SP, Brazil 13418-900
}

\section{ABSTRACT}

This project aimed to evaluate the effects 8 additives on the fermentation, dry matter (DM) losses, nutritive value, and aerobic stability of corn silage. Corn forage harvested at $31 \%$ DM was chopped $(10 \mathrm{~mm})$ and treated with (1) deionized water (control); (2) Buchneri 500 (BUC; $1 \times 10^{5} \mathrm{cfu} / \mathrm{g}$ of Pediococcus pentosaceus 12455 and $4 \times 10^{5} \mathrm{cfu} / \mathrm{g}$ of Lactobacillus buchneri 40788; Lallemand Animal Nutrition, Milwaukee, WI); (3) sodium benzoate (BEN; 0.1\% of fresh forage); (4) Silage Savor acid mixture (SAV: $0.1 \%$ of fresh forage; Kemin Industries Inc., Des Moines, IA); (5) $1 \times 10^{6} \mathrm{cfu} / \mathrm{g}$ of Acetobacter pasteurianus-ATCC 9323; (6) $1 \times 10^{6} \mathrm{cfu} / \mathrm{g}$ of Gluconobacter oxydans-ATCC 621; (7) Ecosyl 200T (1 $\times 10^{5} \mathrm{cfu} / \mathrm{g}$ of Lactobacillus plantarum MTD/1; Ecosyl Products Inc., Byron, IL); (8) Silo-King WS $\left(1.5 \times 10^{5}\right.$ cfu/g of L. plantarum, P. pentosaceus and Enterococcus faecium; Agri-King, Fulton, IL); and (9) Biomax 5 (BIO; $1 \times 10^{5} \mathrm{cfu} / \mathrm{g}$ of L. plantarum PA-28 and K-270; Chr. Hansen Animal Health and Nutrition, Milwaukee, WI). Treated forage was ensiled in quadruplicate in mini silos at a density of $172 \mathrm{~kg}$ of $\mathrm{DM} / \mathrm{m}^{3}$ for 3 and $120 \mathrm{~d}$. After $3 \mathrm{~d}$ of ensiling, the $\mathrm{pH}$ of all silages was below 4 but ethanol concentrations were least in BEN silage (2.03 vs. $3.24 \% \mathrm{DM}$ ) and lactic acid was greatest in SAV silage (2.97 vs. $2.51 \%$ DM). Among $120-\mathrm{d}$ silages, additives did not affect DM recovery (mean = $89.8 \% \pm 2.27$ ) or in vitro DM digestibility (mean = $71.5 \% \pm 0.63)$. The SAV silage had greater ammonia-N $(0.85 \mathrm{~g} / \mathrm{kg}$ of DM) and butyric acid (0.22 vs. $0.0 \% \mathrm{DM})$ than other treatments. In contrast, BEN and Silo-King silages had the least ammonia-N concentration and had no butyric acid. The BEN and A. pasteurianus silages had the lowest $\mathrm{pH}$ (3.69) and BEN silage had the least ethanol $(1.04 \% \mathrm{DM})$ and ammonia nitrogen $(0.64 \mathrm{~g} /$ $\mathrm{kg}$ DM) concentrations, suggesting that fermentation was more extensive and protein degradation was less in BEN silages. The BUC and BIO silages had greater acetic acid concentrations than control silages (3.19 and 3.19 vs. $2.78 \% \mathrm{DM})$, but yeast counts did not differ.

Received February 12, 2013.

Accepted April 20, 2013.

${ }^{1}$ Corresponding author: adesogan@ufl.edu
Aerobic stability was increased by $64 \%$ by BUC ( 44.30 h) and by $35 \%$ by BEN (36.49 h), but other silages had similar values $(27.0 \pm 1.13 \mathrm{~h})$.

Key words: silage inoculant, chemical additive, corn silage, aerobic stability

\section{INTRODUCTION}

Additives are added to ensiled forages to prevent or reduce the growth of undesirable microorganisms in silages and thus enhance silage fermentation and aerobic stability (Kleinschmit and Kung, 2006a; Pedroso et al., 2010). Inorganic acids, such as formic or sulfuric acids, have been successfully used to improve silage preservation by direct acidification (Kung et al., 2003), whereas organic acids with strong antifungal properties, such as propionic, benzoic, and sorbic acids, have been used to increase silage aerobic stability (Kleinschmit et al., 2005). The antimicrobial properties of these acids result from their ability to pass across the cell membrane in the undissociated form and release hydrogen in the cytoplasm. The resulting reduction in cytoplasmic $\mathrm{pH}$ or the use of ATP to resist the $\mathrm{pH}$ decline and maintain homeostasis causes the cell to reduce or stop growing (Lambert and Stratford, 1999).

Homofermentative bacterial inoculants ferment water-soluble carbohydrates into organic acids, particularly lactic acid, which rapidly acidifies the silage and inhibits the growth of undesirable bacteria. Heterolactic inoculant bacteria ferment water-soluble carbohydrates into antifungal acids, such as acetic and propionic acids, which inhibit the growth of spoilagecausing fungi (Huisden et al., 2009; Filya and Sucu, 2010). Commercially available inoculants contain one or both types of lactic acid bacteria (LAB), but few studies have simultaneously compared several of the available inoculants with chemical additives.

Recently, Nishino et al. (2009) suggested that acetic acid bacteria (AAB) could be used to improve silage aerobic stability after discovering high concentrations of acetic acid in aerobically exposed corn silages contaminated with high populations of Acetobacter pasteurianus. This concept requires validation, as it contradicts the notion that $\mathrm{AAB}$ can initiate aerobic 
spoilage (Spoelstra et al., 1988). Acetic acid bacteria in the Gluconobacter genus can oxidize ethanol to acetic acid by using alcohol and acetaldehyde dehydrogenase, but cannot completely oxidize acetic or lactic acid because they lack the pertinent enzymes (De Ley, 1961; Schweigeret al., 2007). Thus, the proliferation of such bacteria after ensiling may result in greater residual acetic and lactic acid concentrations in aerobically exposed silages (Holt et al., 1994), which could increase aerobic stability. Research is needed to examine the effects of applying Gluconobacter inoculants to silages prone to ethanolic fermentations, such as most sugarcane silages (Schmidt, 2009; Nussio et al., 2009) and some corn silages.

Few studies have simultaneously compared several bacterial and chemical additives for improving silage preservation. This project aimed to evaluate the effect of various existing chemical additives and LAB inoculants and 2 novel AAB inoculants on the fermentation, DM losses, nutritive value, and aerobic stability of corn silages.

\section{MATERIALS AND METHODS}

\section{Silage, Treatments, and Design}

The study was conducted from November 2010 to February 2011 at the Dairy Research Unit, University of Florida, Gainesville. Fresh corn forage (Dekalb 69-70, Monsanto, St. Louis, MO) was harvested at 31\% of DM and chopped to lengths of approximately 10 $\mathrm{mm}$. Additives were diluted in $100 \mathrm{~mL}$ of deionized water and sprayed in a fine mist on 100-kg forage piles under constant mixing. The treatments applied were (1) water alone (control; CONT); (2) Buchneri 500 applied at $1 \times 10^{5} \mathrm{cfu} / \mathrm{g}$ of Pediococcus pentosaceus 12455 and $4 \times 10^{5} \mathrm{cfu} / \mathrm{g}$ of Lactobacillus buchneri 40788 (BUC; Lallemand Animal Nutrition, Milwaukee, WI); (3) sodium benzoate applied at $0.1 \%$ of fresh forage (BEN); (4) Silage Savor (SAV; a mixture of propionic, benzoic, lactic, and sorbic acids applied at $0.1 \%$ of fresh forage; Kemin Industries Inc., Des Moines, IA); (5) 1 $\times 10^{6} \mathrm{cfu} / \mathrm{g}$ of Acetobacter pasteurianus-ATCC 9323 (PAS); (6) $1 \times 10^{6} \mathrm{cfu} / \mathrm{g}$ of Gluconobacter oxydansATCC 621 (SUB); (7) Ecosyl 200T applied at $1 \times 10^{5}$ $\mathrm{cfu} / \mathrm{g}$ of Lactobacillus plantarum MTD/1 (ECO; Ecosyl Products Inc., Byron, IL); (8) Silo-King WS inoculant applied at $1.5 \times 10^{5} \mathrm{cfu} / \mathrm{g}$ of L. plantarum, Pediococcus pentosaceus, and Enterococcus faecium (SK; Agri-King, Fulton, IL); and (9) Biomax 5 inoculant applied at $1 \times$ $10^{5} \mathrm{cfu} / \mathrm{g}$ of L. plantarum PA-28 and K-270 (BIO; Chr. Hansen Animal Health and Nutrition, Milwaukee, WI). Treated forages were packed in quadruplicate at a density of approximately $172 \mathrm{~kg}$ of $\mathrm{DM} / \mathrm{m}^{3}$ into separate 3 - and 20-L laboratory silos, which were sealed for 3 and $120 \mathrm{~d}$, respectively, and kept at ambient temperature $\left(25^{\circ} \mathrm{C}\right)$ in an enclosed barn. The 3 -L silos were 6 - $\mathrm{mm}$ thick plastic bags sealed with plastic cable ties, and the 20 -L $(30 \times 30 \mathrm{~cm})$ silos were plastic buckets sealed with airtight lids. Silage samples collected on d 3 were analyzed for $\mathrm{pH}$, ammonia, ethanol, VFA, and lactate. In addition, samples from d 120 were also analyzed for chemical composition, DM digestibility, DM losses, and aerobic stability.

\section{Laboratory Analysis}

Oven DM was measured by drying silage samples at $60^{\circ} \mathrm{C}$ for $48 \mathrm{~h}$ in a forced-air oven. Dried samples were ground to pass the 1-mm screen of a Wiley mill (A. H. Thomas, Philadelphia, PA) and analyzed for ash in a muffle furnace at $512^{\circ} \mathrm{C}$ for $8 \mathrm{~h}$. Concentrations of $\mathrm{NDF}, \mathrm{ADF}$, and ADL were measured in an ANKOM 200 Fiber Analyzer (Ankom Technologies, Macedon, NY) using methods of Van Soest et al. (1991) for NDF and AOAC (1990) for ADF and ADL. Heat-stable $\alpha$-amylase and sodium sulfite were used in the NDF assay and the results are presented inclusive of residual ash. Nitrogen was determined by rapid combustion using a Macro elemental $\mathrm{N}$ analyzer (Vario MAX CN, model ID 25.00-5003; Elementar, Hanau, Germany) and $\mathrm{CP}$ was calculated as $\mathrm{N} \times 6.25$. Acid-detergent insoluble nitrogen was quantified by a modification of the method described by Licitra et al. (1996), which involved $\mathrm{N}$ quantification by rapid combustion using the $\mathrm{N}$ analyzer described above instead of using titration. In vitro true DM digestibility was measured with the method of Van Soest et al. (1966). Ammonia-N was measured by distillation (AOAC, 1985). Starch was quantified by measuring free glucose after sample incubation with amyloglucosidase at $60^{\circ} \mathrm{C}$ for $30 \mathrm{~min}$ (Holm et al., 1986).

Silage extract was prepared by mixing $25 \mathrm{~g}$ of corn silage with $225 \mathrm{~mL}$ of $0.1 \%$ peptone water in a stomacher for $3 \mathrm{~min}$. The solution was filtered through 2 layers of cheesecloth and an aliquot was immediately used for yeast, mold, and clostridia counts, as described by FDA (1998). Briefly, the aliquot obtained from the silage extract was diluted 10-fold and inoculated in triplicate on agar plates containing (1) de Man-RogosaShape agar (Thermo Scientific-Remel, Pittsburgh, PA; R01585) and incubated at $48 \mathrm{~h}$ at $32^{\circ} \mathrm{C}$ to enumerate lactobacilli, (2) malt extract agar (Thermo ScientificOxoid, OXCM0059B) and incubated at $72 \mathrm{~h}$ at $32^{\circ} \mathrm{C}$ to enumerate yeast and molds, and (3) tryptose sulfite cycloserine agar (Thermo Scientific, CM0587B) and inoculated for $24 \mathrm{~h}$ at $35^{\circ} \mathrm{C}$ to enumerate clostridia and Brilliant Green lactose bile broth, 2\% (Fluka, 16025) 
incubated at $48 \mathrm{~h}$ at $35^{\circ} \mathrm{C}$ to enumerate coliforms. The $\mathrm{pH}$ of the silage was measured using an electrode (Corning Model 12, Corning Scientific Instruments, Medfield, MA). An aliquot of $2 \mathrm{~mL}$ of silage extract was centrifuged at $2,000 \times g$ for $15 \mathrm{~min}$ at $4^{\circ} \mathrm{C}$ and the supernatant was filtered with a $0.22-\mu \mathrm{m}$ syringe filter and used to quantify lactic acid and VFA by HPLC (Merck Hitachi, Elite Lachrom HTA, Tokyo, Japan). A UV detector (Merck Hitachi L-2400) set at $210 \mathrm{~nm}$ and a Bio-Rad Aminex HPX-87H column (Bio-Rad Laboratories, Hercules, CA) with 0.015- $M$ sulfuric acid mobile phase and a flow rate of $0.7 \mathrm{~mL} / \mathrm{min}$ at $45^{\circ} \mathrm{C}$ were used (Arriola et al., 2011). Ethanol was measured with an HPLC (Merck Hitachi) coupled to a refractive index detector (Merck Hitachi L-2490).

Aerobic stability was measured by placing $2 \mathrm{~kg}$ of silage in an open-top polystyrene box. Temperature sensors (HOBO temperature data logger $64 \mathrm{k}$, Onset Computer Corporation, Cape Cod, MA) were placed at the geometric center of each silage sample and data were recorded every $30 \mathrm{~min}$ for $14 \mathrm{~d}$. Four additional sensors were placed in the room to record ambient temperature. Silages were covered with 2 layers of cheesecloth to prevent drying. Aerobic stability was denoted as the length of time that elapsed before silage and ambient temperatures differed by more than $2^{\circ} \mathrm{C}$. Weights of empty and full silos at ensiling and opening were recorded for estimation of DM losses.

\section{Statistical Analysis}

The experiment had a completely randomized design with 9 treatments, 2 ensiling durations, and 4 replicates per treatment. Data from each ensiling period was analyzed separately using the General Linear Model procedure of SAS (SAS Institute Inc., Cary, NC) and a model including treatment and replicate effects. Differences between means were determined using the PDIFF procedure of SAS, which differentiates means based on Fisher's F-protected least significant difference test. Significant differences were declared at $P<$ 0.05 and tendencies to significance at $0.05>P<0.1$.

\section{RESULTS AND DISCUSSION}

The chemical composition of the corn forage (Table 1) was similar to that in previous studies (Kleinschmit and Kung, 2006a; Kim and Adesogan, 2006; Arriola et al., 2011) except for lower lignin concentrations in the hybrid in this study. Most chemical component concentrations and counts of epiphytic molds, coliforms, and LAB were unaffected $(P>0.05)$ by treatment but epiphytic LAB counts were generally high (8.44-8.69 $\log \mathrm{cfu} / \mathrm{g})$. For unknown reasons, BEN forage had slightly greater lignin (2.67 vs. $2.27 \% ; P=0.003)$ and ADIN (0.42 vs. $0.30 \% ; P=0.02)$ concentrations than the CONT forage and ash concentrations were lower $(P=0.003)$ in BEN, BIO, and SK forages than the CONT and PAS forages. The BEN forage had the fewest epiphytic yeasts followed by SAV forage (5.94 and $6.45 \log \mathrm{cfu} / \mathrm{g}$, respectively; $P=0.001)$. Epiphytic clostridia counts were fewer in BIO forage compared with the CONT forage $(0.77$ vs. $1.69 \log \mathrm{cfu} / \mathrm{g} ; P=$ 0.03). The fewer epiphytic yeasts in BEN and SAV forage probably reflect the antifungal properties of these chemicals but the reason why epiphytic clostridia were fewer in BIO silage is unclear. Although BIO contained L. plantarum, which can synthesize bacteriocins against clostridia (Okereke and Montville, 1991), it is unlikely that bacteriocin production explains the response because of the short time between treatment application and sampling $(<30 \mathrm{~min})$.

After $3 \mathrm{~d}$ of ensiling, all silages had $\mathrm{pH}$ values below the threshold of 4 and no butyric acid was detected in the samples (Table 2). Control silage had the lowest $(P<0.001) \mathrm{pH}$ value $(3.76)$ and SK silage had the greatest value $(P<0.001 ; 3.92)$, reflecting differences in their respective lactic acid concentrations (2.57 vs. $2.30 \% ; P<0.001)$. Nevertheless, all $\mathrm{pH}$ values were less than 4 , indicating that all forages were adequately fermented. All treatments except BEN increased acetic acid concentration (1.36 vs. $1.10 \% ; P<0.001)$ but the increase was less for BUC and PAS silages than the others. That acetic acid rather than lactic acid was increased by BIO, ECO, and SK indicates that the homofermentative bacteria in these inoculants did not dominate the epiphytic heterofermentative LAB population during the first $3 \mathrm{~d}$ of ensiling. This is likely because the epiphytic LAB population $\left(3.56 \times 10^{8}\right)$ was greater than normal maximum estimates on forages $\left(10^{6}\right.$; Pahlow et al., 2003). Based on estimates that the inoculant bacterial population must be 2- (Pahlow, 1991 ) to 10-fold (Pitt and Leibensperger, 1987) greater than the epiphytic LAB population to dominate the latter, none of the inoculants supplied sufficient bacteria for dominance.

Residual oxygen in silage can impair the growth rate of some homofermentative bacteria, such as L. plantarum (Kung et al., 2003), which was the only inoculant in present in SK, ECO, and BIO. Pediococcus pentosaceus is more resistant to low doses of oxygen and higher $\mathrm{pH}$ during early stages of fermentation than $L$. plantarum (Lin et al., 1992), but the presence of this organism in SK did not result in increased lactic acid synthesis or a lower $\mathrm{pH}$.

The increase in acetic acid by BUC after $3 \mathrm{~d}$ is probably a reflection of the combined action of the $L$. buchneri in BUC and the epiphytic heterofermentative 
Table 1. Effect of chemical and bacterial additives ${ }^{1}$ on the chemical composition and microbial counts of corn forage on $\mathrm{d} 0$

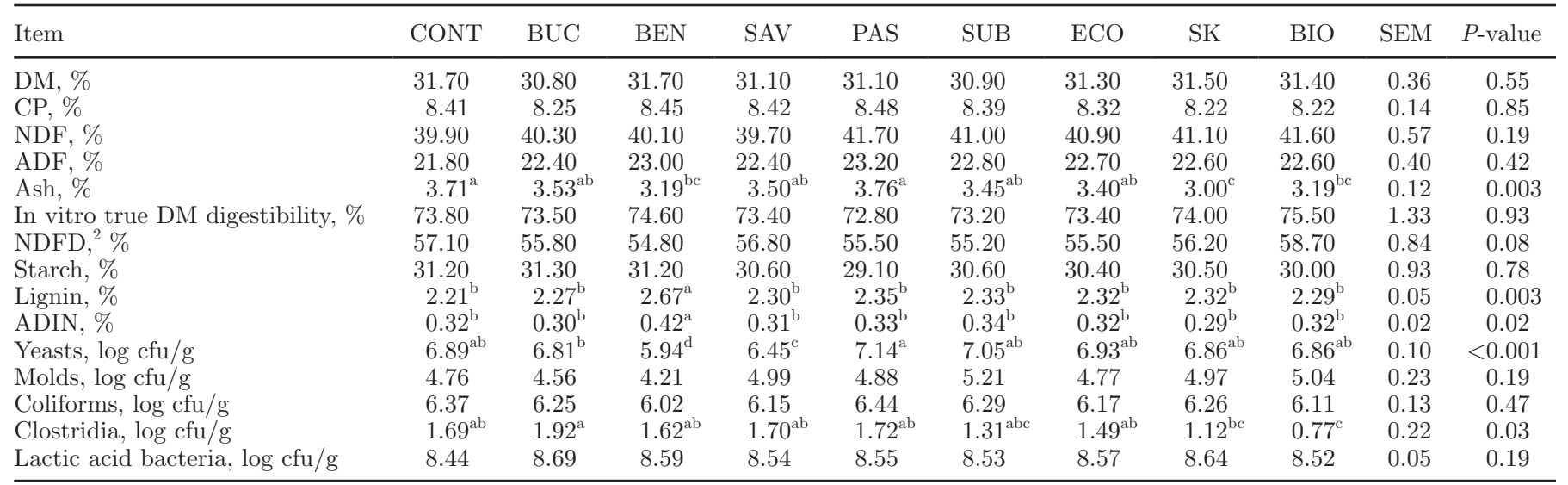

${ }^{\mathrm{a}-\mathrm{d}}$ Means within rows with unlike superscripts differ $(P<0.05)$.

${ }^{1} \mathrm{CONT}=$ water; $\mathrm{BUC}=$ Buchneri 500 (Lallemand Animal Nutrition, Milwaukee, WI) at $1 \times 10^{5} \mathrm{cfu} / \mathrm{g}$ of Pediococcus pentosaceus and $4 \times 10^{5}$ $\mathrm{cfu} / \mathrm{g}$ of Lactobacillus buchneri; BEN = sodium benzoate at $0.1 \%$ of fresh forage; SAV = Silage Savor (Kemin Industries Inc., Des Moines, IA) at $0.1 \%$ of fresh forage; PAS $=1 \times 10^{6} \mathrm{cfu} / \mathrm{g}$ of Acetobacter pasteurianus; SUB $=1 \times 10^{6} \mathrm{cfu} / \mathrm{g}$ of Glucanobacter oxydans; ECO = Ecosyl $200 \mathrm{~T}$ (Ecosyl Products Inc., Byron, IL) at $1 \times 10^{5} \mathrm{cfu} / \mathrm{g}$ of Lactobacillus plantarum; SK $=$ Silo-King (Agri-King, Fulton, IL) at $1.5 \times 10^{5}$ cfu/g of $L$. plantarum, P. pentosaceus, and Enterococcus faecium; BIO = Biomax $5\left(\mathrm{Chr}\right.$. Hansen Animal Health and Nutrition, Milwaukee, WI) at $1 \times 10^{5}$ $\mathrm{cfu} / \mathrm{g}$ of L. plantarum.

${ }^{2}$ Neutral detergent fiber digestibility.

LAB. Filya (2003) reported an increase in acetate after $2 \mathrm{~d}$ of ensiling in corn silage treated with $L$. buchneri. These effects are unlikely to be due to conversion of lactic acid to acetic acid and 1,2-propanediol by $L$. buchneri (Oude Elferink et al., 2001), as the conversion often takes at least $56 \mathrm{~d}$ (Kleinschmit and Kung (2006a). The increase in acetic acid observed in PAS and SUB silages (1.10 vs. 1.27 and $1.4 \%$ DM; $P<$ 0.001 ) is attributable to the $\mathrm{AAB}$ in these inoculants. In the presence of residual oxygen and ethanol, alcohol and aldehyde dehydrogenases produced by Acetobacter and Gluconobacter can convert ethanol to acetic acid (Yakushi and Matsushita, 2010).

The high ethanol concentration observed in all 3-d silages was probably caused by the high epiphytic population of yeasts $\left(6.77 \log \mathrm{cfu} / \mathrm{g}\right.$ or $\left.5.9 \times 10^{6}\right)$, which exceeds the typical maximum population of $1 \times 10^{5}$ (Pahlow et al., 2003). Filya and Sucu (2010) reported similarly high ethanol concentrations in corn forage ensiled for $4 \mathrm{~d}$. Benzoate was the only treatment that reduced ethanol concentration below that of CONT silage ( 2.03 vs. $3.07 \%$ DM; $P<0.001$ ), reflecting the antimycotic nature of the chemical. Ammonia-N concentration was decreased by all treatments except BUC and SAV (0.23 and $0.42 \mathrm{~g} / \mathrm{kg}$, respectively; $P<0.001$ ), suggesting that proteolysis was reduced by most additive treatments.

Additive treatment did not affect $(P>0.05)$ concentrations of DM, ADF, starch, and ADIN or in vitro digestibility after $120 \mathrm{~d}$ of ensiling (Table 3 ). The BUC

Table 2. Effect of chemical and bacterial additives ${ }^{1}$ on the fermentative parameters of corn silage after $3 \mathrm{~d}$ of fermentation

\begin{tabular}{|c|c|c|c|c|c|c|c|c|c|c|c|}
\hline Item & CONT & BUC & BEN & SAV & PAS & SUB & $\mathrm{ECO}$ & SK & $\mathrm{BIO}$ & SEM & $P$-value \\
\hline $\mathrm{DM}, \%$ & 29.90 & 29.90 & 30.10 & 28.80 & 29.70 & 29.20 & 29.20 & 29.80 & 29.20 & 0.47 & 0.56 \\
\hline $\mathrm{pH}$ & $3.76^{\mathrm{g}}$ & $3.78^{\mathrm{f}}$ & $3.87^{\mathrm{bc}}$ & $3.83^{\mathrm{d}}$ & $3.85^{\mathrm{c}}$ & $3.85^{\mathrm{c}}$ & $3.81^{\mathrm{e}}$ & $3.92^{\mathrm{a}}$ & $3.89^{\mathrm{b}}$ & 0.01 & $<0.001$ \\
\hline Lactate $(\mathrm{L}), \%$ of DM & $2.57^{\mathrm{bc}}$ & $2.62^{\mathrm{b}}$ & $2.38^{\text {cde }}$ & $2.97^{\mathrm{a}}$ & $2.48^{\text {bcde }}$ & $2.52^{\mathrm{bcd}}$ & $2.46^{\text {bcde }}$ & $2.30^{\mathrm{e}}$ & $2.32^{\mathrm{de}}$ & 0.07 & $<0.001$ \\
\hline L:A ratio & $2.34^{\mathrm{a}}$ & $2.15^{\mathrm{b}}$ & $2.21^{\mathrm{ab}}$ & $2.11^{\mathrm{b}}$ & 1.95 & $1.78^{\mathrm{d}}$ & $1.74^{\mathrm{de}}$ & $1.66^{\mathrm{de}}$ & $1.58^{\mathrm{e}}$ & 0.37 & $<0.001$ \\
\hline Ethanol, \% of DM & $3.07^{\mathrm{c}}$ & $3.28^{\mathrm{bc}}$ & $2.03^{\mathrm{d}}$ & $3.53^{\mathrm{ab}}$ & $3.27^{\mathrm{bc}}$ & $3.41^{\mathrm{ab}}$ & $3.39^{\mathrm{b}}$ & $3.68^{\mathrm{a}}$ & $3.50^{\mathrm{ab}}$ & 0.09 & $<0.001$ \\
\hline Ammonia-N, g/kg of DM & $0.24^{\mathrm{b}}$ & $0.23^{\mathrm{b}}$ & $0.22^{\mathrm{c}}$ & $0.42^{\mathrm{a}}$ & $0.21^{\mathrm{cd}}$ & $0.21^{\mathrm{cd}}$ & $0.19^{\mathrm{d}}$ & $0.17^{\mathrm{e}}$ & $0.16^{\mathrm{e}}$ & 0.01 & $<0.001$ \\
\hline
\end{tabular}

${ }^{\mathrm{a}-\mathrm{g}}$ Means within rows with unlike superscripts differ $(P<0.05)$.

${ }^{1} \mathrm{CONT}=$ water; $\mathrm{BUC}=$ Buchneri 500 (Lallemand Animal Nutrition, Milwaukee, WI) at $1 \times 10^{5}$ cfu/g of Pediococcus pentosaceus and $4 \times 10^{5}$ $\mathrm{cfu} / \mathrm{g}$ of Lactobacillus buchneri $\mathrm{BEN}=$ sodium benzoate at $0.1 \%$ of fresh forage; SAV = Silage Savor (Kemin Industries Inc., Des Moines, IA) at $0.1 \%$ of fresh forage; PAS $=1 \times 10^{6} \mathrm{cfu} / \mathrm{g}$ of Acetobacter pasteurianus; SUB $=1 \times 10^{6} \mathrm{cfu} / \mathrm{g}$ of Glucanobacter oxydans; ECO $=$ Ecosyl $200 \mathrm{~T}$ (Ecosyl Products Inc., Byron, IL) at $1 \times 10^{5} \mathrm{cfu} / \mathrm{g}$ of Lactobacillus plantarum; SK $=$ Silo-King (Agri-King, Fulton, IL) at $1.5 \times 10^{5}$ cfu/g of $L$. plantarum, P. pentosaceus, and Enterococcus faecium; $\mathrm{BIO}=$ Biomax $5\left(\mathrm{Chr}\right.$. Hansen Animal Health and Nutrition, Milwaukee, WI) at $1 \times 10^{5}$ $\mathrm{cfu} / \mathrm{g}$ of L. plantarum. 
Table 3. Effect of chemical and bacterial additives $^{1}$ on the chemical composition and in vitro digestibility of corn silage after 120 d of fermentation

\begin{tabular}{|c|c|c|c|c|c|c|c|c|c|c|c|}
\hline Item & CONT & BUC & BEN & SAV & PAS & SUB & $\mathrm{ECO}$ & SK & $\mathrm{BIO}$ & SEM & $P$-value \\
\hline $\mathrm{CP}, \%$ & $8.27^{\mathrm{b}}$ & $8.62^{\mathrm{a}}$ & $7.91^{\mathrm{c}}$ & $8.29^{\mathrm{ab}}$ & $8.26^{\mathrm{b}}$ & $8.43^{\mathrm{ab}}$ & $8.15^{\mathrm{bc}}$ & $8.41^{\mathrm{ab}}$ & $8.14^{\mathrm{c}}$ & 0.11 & 0.01 \\
\hline NDF, $\%$ & $41.20^{\mathrm{cd}}$ & $42.20^{\mathrm{bcd}}$ & $41.20^{\mathrm{d}}$ & $43.70^{\mathrm{abc}}$ & $44.00^{\mathrm{ab}}$ & $44.40^{\mathrm{ab}}$ & $44.90^{\mathrm{a}}$ & $44.60^{\mathrm{ab}}$ & $45.70^{\mathrm{a}}$ & 0.86 & 0.01 \\
\hline Ash, $\%$ & $3.65^{\mathrm{ab}}$ & $3.44^{\mathrm{bc}}$ & $3.41^{\mathrm{bc}}$ & $3.30^{\mathrm{c}}$ & $3.38^{\mathrm{bc}}$ & $3.35^{\mathrm{bc}}$ & $3.62^{\mathrm{abc}}$ & $3.83^{\mathrm{a}}$ & $3.85^{\mathrm{a}}$ & 0.11 & 0.01 \\
\hline In vitro true DM digestibility, $\%$ & 71.8 & 71.80 & 71.10 & 70.90 & 70.50 & 72.30 & 71.80 & 71.70 & 71.50 & 0.63 & 0.62 \\
\hline Starch, \% & 28.90 & 28.60 & 28.60 & 27.90 & 26.90 & 26.20 & 26.20 & 26.30 & 25.10 & 0.96 & 0.09 \\
\hline
\end{tabular}

${ }^{\mathrm{a}-\mathrm{d}}$ Means within rows with unlike superscripts differ $(P<0.05)$.

${ }^{1} \mathrm{CONT}=$ water; $\mathrm{BUC}=$ Buchneri 500 (Lallemand Animal Nutrition, Milwaukee, WI) at $1 \times 10^{5} \mathrm{cfu} / \mathrm{g}$ of Pediococcus pentosaceus and $4 \times 10^{5}$ $\mathrm{cfu} / \mathrm{g}$ of Lactobacillus buchneri; BEN = sodium benzoate at $0.1 \%$ of fresh forage; SAV = Silage Savor (Kemin Industries Inc., Des Moines, IA) at $0.1 \%$ of fresh forage; PAS $=1 \times 10^{6} \mathrm{cfu} / \mathrm{g}$ of Acetobacter pasteurianus; SUB $=1 \times 10^{6} \mathrm{cfu} / \mathrm{g}$ of Glucanobacter oxydans; ECO = Ecosyl $200 \mathrm{~T}$ (Ecosyl Products Inc., Byron, IL) at $1 \times 10^{5} \mathrm{cfu} / \mathrm{g}$ of Lactobacillus plantarum; SK $=$ Silo-King (Agri-King, Fulton, IL) at $1.5 \times 10^{5}$ cfu/g of $L$. plantarum, P. pentosaceus, and Enterococcus faecium; BIO = Biomax $5\left(\right.$ Chr. Hansen Animal Health and Nutrition, Milwaukee, WI) at $1 \times 10^{5}$ cfu/g of L. plantarum.

silage had greater CP concentration than the CONT silage (8.62 vs. $8.27 \% ; P=0.01$ ), whereas BEN and BIO silages had slightly lower concentrations (7.91 and $8.14 \%$, respectively; $P=0.01$ ). Compared with the CONT silage, SAV silage had less ash (3.30 vs. $3.65 \%$ $\mathrm{DM} ; P=0.01$ ), and all silages except BUC and SAV silage had more lignin. Though statistically different $(P<0.05)$, treatment effects on $\mathrm{CP}$, ash, and lignin were relatively small and are unlikely to be biologically significant.

The NDF concentrations of PAS, SUB, ECO, SK, and BIO silages were approximately 3 percentage units greater $(P=0.006)$ than those of the CONT silage, and starch concentrations tended $(P=0.09)$ to be at least 2 percentage units less in these silages than the CONT silages. These differences may reflect greater utilization of fermentable carbohydrates by these additives.

The BEN silage had a lower $\mathrm{pH}(3.67, P=0.001)$ than all others except PAS, however, the $\mathrm{pH}$ range was relatively narrow (3.67 to 3.75$)$ and all values were below 4 (Table 4 ), indicating that all silages were well fermented. Lactic acid concentrations tended to be less $(P=0.09)$ in treated versus CONT silages and BUC, and BIO silages had greater $(P=0.04)$ acetic acid concentrations $(3.19 \%)$ than CONT (2.72), BEN $(2.48 \%)$, and PAS (2.64) silages. The greater acetic acid concentration of BUC and BIO silages agrees with the data from silages ensiled for $3 \mathrm{~d}$. The reason why BUC increased acetate concentration was described earlier, but it is not clear why a similar increase occurred in $\mathrm{BIO}$, which only contains 2 strains of $L$. plantarum.

Treatments BUC, SAV, SUB, ECO, and BIO resulted in lower lactic to acetic acid ratios than the CONT $(1.66,1.78,1.81,1.88$, and 1.70 vs. $2.18 \%$, respectively; $P<0.01)$, indicating that they made the fermentation more heterofermentative. Dry matter recovery $(P$ $=0.66)$ did not differ among treatments (average of $89.7 \%$ ), though CONT, PAS, BUC, and BIO silages

Table 4. Effect of chemical and bacterial additives ${ }^{1}$ on the fermentation parameters and yeast counts of corn silage after $120 \mathrm{~d}$ of fermentation

\begin{tabular}{|c|c|c|c|c|c|c|c|c|c|c|c|}
\hline Item & CONT & $\mathrm{BUC}$ & BEN & SAV & PAS & SUB & ECO & SK & $\mathrm{BIO}$ & SEM & $P$-value \\
\hline $\mathrm{pH}$ & $3.71^{\mathrm{abc}}$ & $3.73^{\mathrm{abc}}$ & $3.67^{\mathrm{d}}$ & $3.75^{\mathrm{a}}$ & $3.70^{\mathrm{cd}}$ & $3.71^{\mathrm{bc}}$ & $3.72^{\mathrm{abc}}$ & $3.73^{\mathrm{abc}}$ & $3.74^{\mathrm{ab}}$ & 0.01 & 0.001 \\
\hline Lactate (L), \% of DM & 5.95 & 5.32 & 5.11 & 5.07 & 5.11 & 5.04 & 5.19 & 5.29 & 5.46 & 0.20 & 0.09 \\
\hline $\mathrm{L}: \mathrm{A}$ ratio & $2.18^{\mathrm{a}}$ & $1.66^{\mathrm{d}}$ & $2.08^{\mathrm{ab}}$ & $1.78^{\mathrm{cd}}$ & $1.95^{\mathrm{abc}}$ & $1.81^{\mathrm{bcd}}$ & $1.88^{\mathrm{bcd}}$ & $1.91^{\mathrm{abcd}}$ & $1.70^{\mathrm{cd}}$ & 0.09 & 0.01 \\
\hline Butyrate, $\%$ of DM & $0.00^{\mathrm{b}}$ & $0.00^{\mathrm{b}}$ & $0.00^{\mathrm{b}}$ & $0.22^{\mathrm{a}}$ & $0.00^{\mathrm{b}}$ & $0.00^{\mathrm{b}}$ & $0.00^{\mathrm{b}}$ & $0.00^{\mathrm{b}}$ & $0.00^{\mathrm{b}}$ & 0.01 & 0.001 \\
\hline Ethanol, \% of DM & $3.26^{\mathrm{ab}}$ & $3.26^{\mathrm{ab}}$ & $1.04^{\mathrm{c}}$ & $3.01^{\mathrm{b}}$ & $3.18^{\mathrm{ab}}$ & $3.04^{\mathrm{b}}$ & $3.06^{\mathrm{b}}$ & $3.28^{\mathrm{ab}}$ & $3.45^{\mathrm{a}}$ & 0.11 & 0.001 \\
\hline
\end{tabular}

${ }^{\mathrm{a}-\mathrm{d}}$ Means within rows with unlike superscripts differ $(P<0.05)$.

${ }^{1} \mathrm{CONT}=$ water; BUC $=$ Buchneri 500 (Lallemand Animal Nutrition, Milwaukee, WI) at $1 \times 10^{5} \mathrm{cfu} / \mathrm{g}$ of Pediococcus pentosaceus and $4 \times 10^{5}$ $\mathrm{cfu} / \mathrm{g}$ of Lactobacillus buchneri; BEN = sodium benzoate at $0.1 \%$ of fresh forage; SAV = Silage Savor (Kemin Industries Inc., Des Moines, IA) at $0.1 \%$ of fresh forage; PAS $=1 \times 10^{6} \mathrm{cfu} / \mathrm{g}$ of Acetobacter pasteurianus; SUB $=1 \times 10^{6} \mathrm{cfu} / \mathrm{g}$ of Glucanobacter oxydans; ECO $=$ Ecosyl $200 \mathrm{~T}$ (Ecosyl Products Inc., Byron, IL) at $1 \times 10^{5} \mathrm{cfu} / \mathrm{g}$ of Lactobacillus plantarum; SK $=$ Silo-King (Agri-King, Fulton, IL) at $1.5 \times 10^{5}$ cfu/g of $L$. plantarum, P. pentosaceus, and Enterococcus faecium; $\mathrm{BIO}=$ Biomax 5 (Chr. Hansen Animal Health and Nutrition, Milwaukee, WI) at $1 \times 10^{5}$ $\mathrm{cfu} / \mathrm{g}$ of L. plantarum. 


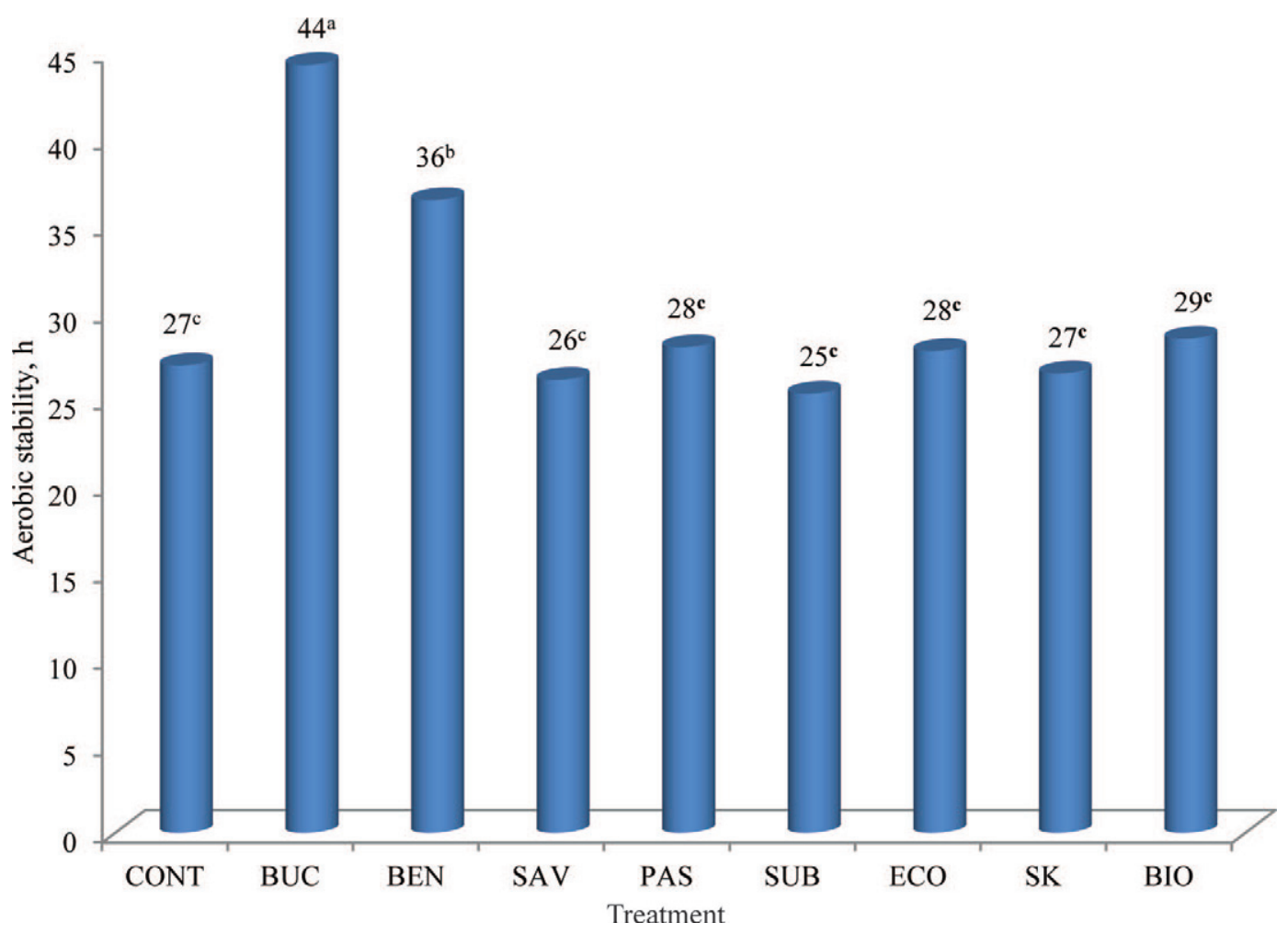

Figure 1. Effect of chemical and bacterial additives on the aerobic stability of corn silage after $120 \mathrm{~d}$ of fermentation. CONT = water; BUC $=1 \times 10^{5} \mathrm{cfu} / \mathrm{g}$ of Pediococcus pentosaceus and $4 \times 10^{5} \mathrm{cfu} / \mathrm{g}$ of Lactobacillus buchneri; BEN $=0.1 \%$ sodium benzoate; SAV $=0.1 \%$ acetic and propionic acid; PAS $=1 \times 10^{6} \mathrm{cfu} / \mathrm{g}$ of Acetobacter pasteurianus; $\mathrm{SUB}=1 \times 10^{6} \mathrm{cfu} / \mathrm{g}$ of Glucanobacter oxydans; ECO $=1 \times 10^{5} \mathrm{cfu} / \mathrm{g}$ of Lactobacillus plantarum; $\mathrm{SK}=1.5 \times 10^{5} \mathrm{cfu} / \mathrm{g}$ of L. plantarum, P. pentosaceus, and Enterococcus faecium; BIO $=1 \times 10^{5} \mathrm{cfu} / \mathrm{g}$ of L. plantarum. Bars with different letters $(\mathrm{a}-\mathrm{c})$ differ $(P<0.05 ; \mathrm{SE}=2.47)$. Color version available in online PDF.

had numerically lower DM recovery than the others (88.1 vs. $91.1 \% ; P>0.1$ ). Butyric acid was only detected in SAV silage $(0.22 \% \mathrm{DM})$, which also had greater ammonia concentrations than others (0.85 vs. $0.70 \mathrm{~g} /$ $\mathrm{kg}$ of DM; $P=0.001)$; but the concentrations were too low to indicate clostridial fermentation (Pahlow et al., 2003), and no clostridia were detected in the silages.

As in those ensiled for $3 \mathrm{~d}$, ethanol concentrations were only reduced by BEN (1.04 vs. $3.26 \% \mathrm{DM} ; P=$ 0.001). Molds and coliforms were not detected in the silages. Yeast counts did not differ with treatment $(P$ $=0.51$ ); however, BEN silages had numerically much lower counts than the CONT silage (1.74 vs. $4.90 \mathrm{log}$ $\mathrm{cfu} / \mathrm{g})$, which partly explains their lower ethanol concentration. Aerobic stability was $64 \%$ greater in BUC versus CONT silage (44.3 h vs. $26.97 \mathrm{~h} ; P=0.002)$ and $35 \%$ greater in BEN versus CONT silage (36.5 vs. $26.97 \mathrm{~h} ; P=0.002)$, but values for CONT and other silages did not differ $(P>0.05$; Figure 1$)$. Huisden et al. (2009) reported that aerobic stability of corn silage inoculated with BUC was doubled when compared with the CONT silages (60.8 vs. $25.5 \mathrm{~h} ; P<0.05)$. Using a meta-analysis, Kleinschmit and Kung (2006b) also reported that L. buchneri increased aerobic stability of corn silage by increasing acetic acid concentration and, consequently, decreasing the fungal population. However, as in the study of Mari et al. (2009), BUC application did not statistically increase the acetic acid concentration or reduce the yeast population in this study, even though it improved aerobic stability.

Application of treatments ECO, SK, and BIO, containing LAB that usually promote a homolactic fermentation, resulted in corn silages with adequate $\mathrm{pH}$ $(3.72,3.73$, and 3.74 vs. 3.71 , respectively) and lactic acid concentrations $(5.19,5.29$, and 5.46 vs. $5.95 \%$, respectively; $P=0.09$ ), but the $\mathrm{pH}$ values were not lower and lactic acid concentrations were not greater than those in the CONT silage. This indicates that the inoculant bacteria did not dominate the epiphytic LAB, which were more numerous (8.56 log $\mathrm{cfu} / \mathrm{g}$ or $3.66 \times 10^{8}$ ) than the typical maximum forage population $\left(1 \times 10^{6} \mathrm{cfu} / \mathrm{g}\right.$; Pahlow et al., 2003). The epiphytic LAB promoted a homolactic fermentation evidenced by higher lactic to acetic acid ratios in CONT silages than almost all treated silages after 3 and $120 \mathrm{~d}$ of ensiling. This may also explain why application of SAV, an acid 
mixture, did not improve the fermentation. Others, such as Weinberg et al. (2007), reported that homolactic or facultative heterolactic bacteria $L$. plantarum did not increase lactic acid concentration or reduce the $\mathrm{pH}$ of corn silage when compared with a control treatment. Such results are attributable to high numbers of epiphytic LAB on the uninoculated corn plant (Kristensen et al., 2010) and the relatively high water-soluble carbohydrate concentration and low buffering capacity of corn plants, which facilitate ensiling.

The initial increase in acetic acid concentrations seen in silages ensiled with $\mathrm{AAB}$ for $3 \mathrm{~d}$ was not maintained after $120 \mathrm{~d}$ of ensiling, confirming that these organisms do not produce acetic acid under anoxic conditions (Holt et al., 1994). Spoelstra et al. (1988) suggested that Acetobacter can initiate spoilage of corn silage, whereas Nishino et al. (2009) suggested that A. pasteurianus increased the aerobic stability of corn silage. Neither of these findings was supported by the AAB tested in this study. Rather our results were similar to those of Kan and Nishino (2011) who reported that A. pasteurianus treatment did not affect the aerobic stability of corn silage.

\section{CONCLUSIONS}

After $3 \mathrm{~d}$ of ensiling, all silages were well fermented $(\mathrm{pH}<4.0)$ and, although no additive reduced the $\mathrm{pH}$ relative to the CONT silage, BEN, PAS, SUB, SK, $\mathrm{ECO}$, and $\mathrm{BIO}$ reduced the ammonia- $\mathrm{N}$ concentration. After $120 \mathrm{~d}$ of ensiling, DM recovery, yeast counts, and in vitro digestibility were unaffected by treatment, and CONT silages had similar $\mathrm{pH}$ to all treated silages except BEN, which had a lower value. Only BUC and $\mathrm{BIO}$ silages increased the acetic acid concentration. The high epiphytic LAB counts (8.44-8.69 log cfu/g) may explain the limited effect of the inoculants and additives on fermentation indices, and the high counts may be due to the hot and humid Florida weather during the growing season. Aerobic stability was $64 \%$ greater in BUC silage and $35 \%$ greater in BEN silage than the CONT silage, but other additives had no effect. Applying $\mathrm{AAB}$ increased acetic acid concentration within $3 \mathrm{~d}$ of ensiling when residual oxygen may have been present, but did not increase acetic acid concentrations or aerobic stability after $120 \mathrm{~d}$ of ensiling.

\section{ACKNOWLEDGMENTS}

The authors gratefully acknowledge funding for this project from Southeast Milk Check-Off (Belleview, FL) and the respective companies for donation of additives and services.

\section{REFERENCES}

AOAC. 1985. Official Methods of Analysis 14th ed. Association of Official Analytical Chemists, Washington, DC.

AOAC. 1990. Official methods of Analysis. 15th ed. Association of Official Analytical Chemists, Arlington, VA.

Arriola, K. G., S. C. Kim, and A. T. Adesogan. 2011. Effect of applying inoculants with heterolactic or homolactic and heterolactic bacteria on the fermentation and quality of corn silage. J. Dairy Sci. 94:1511-1516.

De Ley, J. 1961. Comparative carbohydrate metabolism and a proposal for phylogenetic relationship of the acetic acid bacteria. J. Gen. Microbiol. 24:31-50.

FDA. 1998. Bacteriological Analytical Manual, 8th Edition (Revision A). Accessed Feb. 1, 2012. www.fda.gov/Food/FoodScienceResearch/ LaboratoryMethods/ucm2006949.htm.

Filya, I. 2003. The effect of Lactobacillus buchneri and Lactobacillus plantarum on the fermentation, aerobic stability, and ruminal degradability of low dry matter corn and sorghum silages. J. Dairy Sci. 86:3575-3581.

Filya, I., and E. Sucu. 2010. The effect of lactic acid bacteria on the fermentation, aerobic stability and nutritive value of maize silage. Grass Forage Sci. 65:446-455.

Holm, J. I., I. Bjorck, A. Drews, and N. G. Asp. 1986. A rapid method for the analysis of starch. Starch-Stärke 7:224-226.

Holt, J. G., N. R. Krieg, P. H. A. Sneath, and S. T. Williams. 1994. Bergey's Manual of Determinative Bacteriology, 9th ed. Williams and Wilkins, Baltimore, MD.

Huisden, C. M., A. T. Adesogan, S. C. Kim, and T. Ososanya. 2009. Effect of applying molasses or inoculants containing homofermentative or heterofermentative bacteria at two rates on the fermentation and aerobic stability of corn silage. J. Dairy Sci. 92:690-697.

Kan, K., and N. Nishino. 2011. Inoculation of Acetobacter pasteurianus, either before ensiling or after silo opening, does not enhance aerobic spoilage of corn silage. Pages $127-142$ in Proc. Int. Sym. Forage Qual. Conserv., Piracicaba. J. P. Daniel, M. Zopollatto, and L. G. Nussio, ed. University of São Paulo, Piracicaba, SP, Brazil.

Kim, S. C., and A. T. Adesogan. 2006. Influence of ensiling temperature, simulated rainfall, and delayed sealing on fermentation characteristics and aerobic stability of corn silage. J. Dairy Sci. 89:3122-3132.

Kleinschmit, D. H., and L. Kung. 2006a. The effects of Lactobacillus buchneri 40788 and Pediococcus pentosaceus r1094 on the fermentation of corn silage. J. Dairy Sci. 89:3999-4004.

Kleinschmit, D. H., and L. Kung. 2006b. A meta-analysis of the effects of Lactobacillus buchneri on the fermentation and aerobic stability of corn and grass and small-grain silages. J. Dairy Sci. 89:4005-4013.

Kleinschmit, D. H., R. J. Schmidt, and L. Kung. 2005. The effects of various antifungal additives on the fermentation and aerobic stability of corn silage. J. Dairy Sci. 88:2130-2139.

Kristensen, N. B., K. H. Sioth, O. Højberg, N. H. Spliid, C. Jensen, and R. Thøgersen. 2010. Effects of microbial inoculantes on corn silage fermentation, microbial contents, aerobic stability, and milk production under field conditions. J. Dairy Sci. 93:3764-3774.

Kung, L., M. R. Stokes, and C. J. Lin. 2003. Silage additives. Pages 305-360 in Silage Science and Technology (Agronomy Series No. 42). D. R. Buxton, R. E. Muck, and H. J. Harrison, ed. American Society of Agronomy, Madison, WI.

Lambert, R. J., and M. Stratford. 1999. Weak acid preservatives: Modeling microbial inhibition and response. J. Appl. Microbiol. $86: 157-164$.

Licitra, G., T. M. Hernandez, and P. J. Van Soest. 1996. Standardization of procedures for nitrogen fractionation of ruminant feeds Anim. Feed Sci. Technol. 57:347-358.

Lin, C., K. K. Bolsen, B. E. Brent, and D. Y. C. Fung. 1992. Epiphytic lactic acid bacteria succession during the pre-ensiling and ensiling periods of alfalfa and maize. J. Appl. Bacteriol. 73:375-387.

Mari, L. J., R. J. Schmidt, L. G. Nussio, C. M. Hallada, and L. Kung. 2009. Short communication: An evaluation of the effectiveness of 
Lactobacillus buchneri 40788 to alter fermentation and improve the aerobic stability of corn silage in farm silos. J. Dairy Sci. 92:1174-1176.

Nishino, N., C. Wang, S. Parvin, and K. Kan. 2009. Occurrence and survival in whole crop corn silage of Acetobacter pasteurianus. Page 165-166 in Proc. 15th Int. Silage Conf., U.S. Dairy Forage Research Center. USDA-ARS, Madison, WI.

Nussio, L. G., R. C. Amaral, G. B. Muraro, B. Domeniconi, V. P. Santos, A. L. B. Schogor, J. L. P. Daniel, and G. B. Mourão 2009. An evaluation of the effectiveness of Lactobacillus buchneri to control total losses and improve the aerobic stability of two sugarcane varieties harvested for silage. Page 281-282 in Proc. 15th Int. Silage Conf., US Dairy Forage Research Center. USDA-ARS, Madison, WI.

Okereke, A., and T. J. Montville. 1991. Bacteriocin-mediated inhibition of clostridium botulinum spores by lactic acid bacteria at refrigeration and abuse temperatures. Appl. Environ. Microbiol. 57:3423-3428.

Oude Elferink, S. J. W. H., J. Krooneman, J. C. Gottschal, S. F. Spoelstra, F. Faber, and F. Driehuis. 2001. Anaerobic conversion of lactic acid to acetic acid and 1,2-propanediol by Lactobacillus buchneri. Appl. Environ. Microbiol. 67:125-132.

Pahlow, G. 1991. Role of microflora in forage conservation. Pages 2636 in Proc. Conf. Forage Conserv. Towards 2000. G. Pahlow, and H. Honig, ed. Braunschweig, Germany.

Pahlow, G., R. E. Muck, F. Driehuis, S. J. W. H. Oude Elferink, and S. F. Spoelstra. 2003. Microbiology of ensiling. Pages 31-93 in Silage Sci.Technol. (Agronomy Series No. 42). D. R. Buxton, R. E. Muck, and H. J. Harrison, ed. American Society of Agronomy, Madison, WI.
Pedroso, A. F., A. T. Adesogan, O. C. M. Queiroz, and S. K. Williams. 2010. Control of Escherichia coli O157:H7 in corn silage with or without various inoculants: Efficacy and mode of action. J. Dairy Sci. 93:1098-1104.

Pitt, R. E., and R. Y. Leibensperger. 1987. The effectiveness of silage inoculants: A systems approach. Agric. Syst. 25:27-49.

Schmidt, P. 2009. Improved efficiency of sugarcane ensiling for ruminant supplementation. Pages 47-72 in Proc. Int. Sym. Forage Qual. Conserv. M. Zopollato, G. B. Muraro and L. G. Nussio, ed. University of São Paulo, Piracicaba, SP, Brazil.

Schweiger, P., S. Volland, and U. Deppenmeier. 2007. Overproduction and characterization of two distinct aldehyde-oxidizing enzymes from Gluconobacter oxydans 621H. J. Mol. Microbiol. Biotechnol. 13:147-155.

Spoelstra, S. F., M. G. Courtin, and J. A. C. Van Beers. 1988. Acetic acid bacteria can initiate aerobic deterioration of whole crop maize silage. J. Agric. Sci. 111:127-132.

Van Soest, P. J., J. B. Robertson, and B. A. Lewis. 1991. Methods for dietary fiber, neutral detergent fiber and nonstarch polysaccharides in relation to animal nutrition. J. Dairy Sci. 74:3583-3597.

Van Soest, P. J., R. H. Wine, and L. A. Moore. 1966. Estimation of the free digestibility of forages by the in vitro digestion of cell wails. Page 438 in Proc. 10th Int. Grassl. Congr., Helsinki, Finland.

Weinberg, Z. G., O. Shatz, Y. Chen, E. Yosef, M. Nikbahat, D. BenGhedalia, and J. Miron. 2007. Effect of lactic acid bacteria inoculants on in vitro digestibility of wheat and corn silages. J. Dairy Sci. 90:4754-4762.

Yakushi, T., and K. Matsushita. 2010. Alcohol dehydrogenase of acetic acid bacteria: Structure, mode of action, and applications in biotechnology. Appl. Microbiol. Biotechnol. 86:1257-1265. 